\title{
Shipshape Societies: boat symbolism and political systems in Insular Southeast Asia
}

Shipshape societies: boat symbolism and political systems in Insular Southeast Asia

Sociedad "navemórfa »: Simbolismo del barco y sistemas políticos en el Asia del Sudeste insular

Pierre-Yves Manguin

\section{OpenEdition}

\section{Journals}

Electronic version

URL: https://journals.openedition.org/tc/301

DOI: $10.4000 /$ tc.301

ISSN: 1952-420X

\section{Publisher}

Éditions de l'EHESS

\section{Printed version}

Date of publication: 1 January 2001

Number of pages: $373-400$

ISSN: 0248-6016

\section{Electronic reference}

Pierre-Yves Manguin, "Shipshape Societies: boat symbolism and political systems in Insular Southeast Asia", Techniques \& Culture [Online], 35-36 | 2001, Online since 10 September 2012. connection on 29 September 2022. URL: http://journals.openedition.org/tc/301 ; DOI: https://doi.org/ $10.4000 /$ tc. 301

This text was automatically generated on 29 September 2022.

All rights reserved 


\section{Shipshape Societies: boat symbolism and political systems in Insular Southeast Asia ${ }^{2}$}

Shipshape societies: boat symbolism and political systems in Insular Southeast

Asia

Sociedad « navemórfa »: Simbolismo del barco y sistemas políticos en el Asia del Sudeste insular

Pierre-Yves Manguin

1 Boat motifs appearing in various Southeast Asian cultural contexts were first described in detail when the subject attracted the attention of scholars in the 1930's. On the one hand, Steinmann analysed the motif in terms of the "cult ship »: starting from the description of the Lampung ship-cloths, he compared their motifs with those appearing in shamanistic death rituals among the Dayaks and with the famous Bronze Age canoes of the Dông-son drums. On the other hand, Vroklage concentrated on Eastern Indonesia; except for the occasional comparison of the "death-ship " motif with the Greek's crossing of the river Styx, for a brief outline analysis of the relationship of boat motifs with the then popular "megalithic culture ", or for the repeated mention of the ancient migratory voyage as the origin of the social patterns under discussion, his various articles are basically descriptive (Steinmann 1937, 1940 ; Vroklage, 1936, 1937, 1940).

2 Scattered references to the subject appeared occasionally after the war, but it is only during this last decade that two precious trends have clearly been revived. Art historians, particularly specialists of textiles, have devoted a fair amount of work to the Lampung ship-cloths and to their role in this Sumatran society ${ }^{3}$. The Eastern Indonesian « field of studies » has similarly been the object of renewed interest from a large number of well-trained anthropologists who have used sophisticated analytical tools to study boat symbolism and its meaning within the global social systems they dealt with ${ }^{4}$. 
3 However, to this point, little has been done to integrate in a broader geographical and chronological framework the multiple references to boat symbolism in Insular Southeast Asia. This paper will be an attempt at that, but it will concentrate on one single level of the symbolic discourse, which is that, as we shall see, of the boat as a metaphor for the ordered social group (leaving aside, among others, the higher encompassing macrocosmic order). The relationship of symbolic statements about boats and overseas sailing with exchange systems, the founding of political systems and the legitimization of political power, I will also leave aside in this paper.

4 The retrieval from various categories of historical and anthropological sources of statements pertaining to this specific level the symbolism will shed some light on the development of political systems of the whole of Insular Southeast Asia. I will try to answer the questions posed with, as far as possible, an historian's feeling. Historians, or for that matter specialists of maritime history, have not as yet had their say on this subject $^{5}$.

During the last few decades, let us say to simplify after Van Leur's work, trading patterns in Insular Southeast Asia have been taken into account in the historical process. However, the manner in which the continuous maritime exchanges that have taken place from the dawn of history (within the a rea as well as with the outside world) are related to local perceptions of the environment and the construction of social systems has not as yet been properly assessed. Some of the more obvious features of trade-oriented societies, best described in Insular Southeast Asia after the 15 th century, are now often referred to by French historians as part of a «mentalité de réseau " (a trade-network system of values). However, as one tries to move back in time, classical sources get scarcer and far more difficult to interpret. Historians are thus compelled to make use of both chronological and spatial depth so as to attain an artificial "longue durée", as they simultaneously move along time and distance coordinates. One line of interpretation would say that in doing so they take advantage of the fact that various factors have led to a situation in which chosen cultural features of early Southeast Asian societies may have "survived » in some areas rather than in others : this is tantamount to stating that in most cases, as one moves east from an arbitrary centre somewhere in the Straits area, societies tend to have developed at a different pace; thus exhibiting features now vanished in western areas of the Archipelago. But anthropologists would now rather dispense with concepts like «survivals » and "cultural lag» and would take into account the fact that cultural traits such as the symbol systems we are dealing with are constantly being set aside, developed or reconstructed ${ }^{6}$. This is not the place to discuss these theoretical considerations. However, examples provided in the present paper tend to confirm the latter view : the sets of symbols under study do seem to have been adapted, expanded or altogether abandoned at various places and times throughout Insular Southeast Asia.

6 Dealing (or should one say juggling ?) with such a complex and ever-changing scene, across thousands of years and kilometers should necessarily be done with the utmost caution, and this may not be major quality of this paper. I shall nevertheless take the risk.

7 In 1589, when Juan de Plasencia OFS described the social organization of the Tagalogs in pre-Spanish times, this is what he wrote :

"These chiefs (the datu) ruled over but few people; sometimes as many as a

hundred houses, sometimes even less than thirty. This tribal gathering is called in 
Tagalog a barangay. It was inferred that the reason for giving themselves this name arose from the fact (...) that when they came to this land, the head of the barangay, which is a boat thus called, [...] became a datu. And so, even at the present day, it is ascertained that this barangay in its origin was a family of parents and children, relations and slaves ${ }^{7}$."

This seems to be the first recorded explanation for the similarity between the name of a boat and that of a small social unit. It soon became common reading among the Spanish clerics; when Spanish sources were later analysed by historians, the same exegesis was popularised and it remains today as the official theory, providing a ready-made interpretation of the origins of Philippines' political systems ${ }^{8}$.

9 The Tagalog and Cebuano baranggay/balangay, together with words closely akin in various other languages, do indeed have the meaning of «boat " and «boatload» as well as that of a small socio-political group, for which the Tagalog term baryo (from the Spanish barrio, a city quarter) is now a synonym ${ }^{9}$. But the kind of first-degree interpretation provided by Plasencia, whether devised by himself or provided him by contemporary Philippine informers, should be closely analysed in a broader context before it is accepted at face value.

10 At the present stage, the first remark that comes to the mind is that baranggay-type terms meaning both boat and social groups of variable orders are a common feature of Austronesian languages and societies, whether within the same language or not. Boats and houses, both the container and the contained (the «boat-load» and the «household »), are the fundamental social units and it is no surprise to see that terms such as kabang/bangka and their cognates may mean "boat " in some languages and " house " in others ${ }^{10}$. Similarly, banwa and cognate terms can be found in many Austronesian languages with the meanings of a house (Palawan, Toraja), a larger social group (Javanese, Balinese, Bugis, Malay) or a boat (Javanese [?], Ngaju) ${ }^{11}$.

But there is much more to it than simple semantic relationships. The latter aspect is only one out of the multiple components forming a vast set of cultural values. It is only by examining this whole set that a more reliable explanation for the baranggay-type paradigms will be found. Various communities of Insular Southeast Asia actually produce statements establishing complex homothetic correlations between boats, houses and/or larger social groups. A Bugis text on shipbuilding thus states clearly that " if you go to build a prau, it is just the same as if you go to build a house » (MacKnight and Mukhlis 1979: 279). Houses and boats may even be at times oppposed as in a Palawan myth which tells us about mobile houses and immobile canoes, an order which a young hare-brained girl decides to invert (MacDonald 1979: 60-61). The Torajas' phrase sanglembang, applying to a household, is understood as "living together in a boat » (the word lembang means both a boat and a former adat-territory, now a modern district). In Sumba, during healing rituals, the master of the house is said to be " the master of the boat » (Harahap 1952: 14 ; Clamagirand 1979: 52-53). At a different level of perception one may also quote Marcos de Lisboa's early XVIIth century Vocabulario de la Lengua Bicol, in which the word laygay is glossed as «to order or govern aboard a ship [...]; it also means to govern one's house [hold], telling one's slaves what they ought to do $\aleph^{12}$. The Bajau sea-nomads' social organisation is similarly quite revealing: the extended social group above the basic nuclear family (dwelling in a single houseboat) is that of family alliance, the name of which means « a group of boats travelling or mooring together ». And not so surprisingly, its leader is called nakura a clear 
borrowing from the Malay nakhoda (ultimately from Persian, and meaning « shipmaster ») (Nimmo 1972 : 25-27).

One may further pursue this theme by examining the very consistent references to ships that appear as metaphors for various levels of social organisation in Eastern Indonesia $^{13}$. In most of the latter societies, where people are organised into small political systems, the boat and the house are the principal structural units. They are felt as the best modes available to define and regulate relations among members of the smaller units, between the latter and higher social groups (the village community sphere, or a small political system), and between all these social units and the material world (thus the economic production). They provide models for encompassing various orders of social, political, economic (and cosmological) classifications, together with their expression in myths and rituals. Examples taken in Sawu, Kei or Tanimbar will provide concrete evidence of the ubiquitous references to it. The houses are always perceived in clear correlation with the boat, with parts of them named after the " keel», the "mast», the "sails» or the "rudder $»^{14}$. The inhabitants of the same village look upon themselves as being a group of people who belong to the same "village-boat ". This is the large communal boat which is jointly possessed by the whole community and is used only on special occasions, when the social order needs to be signified and revalidated (marriages, alliance renewals with other communities, warfare, death, etc.). The leader of the community and all the dignitaries have their appointed seats in their "village boat "; these places are duplicated in the boat-shaped meeting place of the village, complete with stem and stern. Ritual dances ate performed in boat order and the songs explicity describe the boat thus mapped on the ground. The village itself, as well as the whole island at times, are spatially organised as a boat and and its crew. The dead are disposed of in boat-burials. Myths refer to early voyages from overseas : the village spatial classification, as that of the communal boat, are said to be a reflexion of the original journey.

13 If one leaps to the western half of the Archipelago, the South Sumatran Lampung immediatly come to the mind. Lampung textiles, and particularly the famous « shipcloths " or "tissus à jonques ", have recently been the object of renewed interest, in the wake of burgeoning researches on Indonesian textiles ${ }^{15}$. From narrow interpretations such as that of Steinmann (" the "junks" are ships of the dead, carrying in the souls of the deceased to the other world »), scholars have progressively widened their scope so as to replace boat-symbolism, and specifically that of ship-cloths, within the context of a total society and its « ancient Indonesian coastal culture » (Holmgren and Spertus 1979). The Lampung ship-cloths were indeed only one part of a vast set of highly symbolic artefacts and representations appearing at every stage of Lampung social life where rites de passage were involved (not to speak of the founding myth that recalls the story of "shipmaster Dampu Awang "; Du Bois 1952:330-332). Most of the artefacts representing ships would actually also have depicted birds (particularly hornbills, as expected), buffaloes, snakes, banners, trees of life, the sun and the moon, etc. Considering the fact that the spectrum of signifieds of each one of these symbolic representations may well have been more than univocal, one is no doubt confronted with exceedingly complex statements of a cosmological order.

In this forest of symbols, I will retain one single, albeit essential, statement : that of the boat as a metaphor for an organ ised social unit. This particular statement is found behind the varied depictions of boats in every one of the rites de passage. Ship-cloths - 
weavings as well as beadworks or mats - were hung on walls or were used to sit on, in rituals linked to birth, circumcision, marriage, leader's adat-meetings, changing of social rank and death. Ship-cloths themselves belonged to different categories: the usage of the largest and most beautiful cloths, some of them $5 \mathrm{~m}$ long (the palepai), a privilege of the highest social ranks, actually seem to have been reserved to the eldest son or the eldest representative of the lineage descending from the founders of the various social groups (marga, suku, kampung). Other artefacts such as the bride's headgear or the brass containers (for sirih or blackening the teeth) were also shaped like boats.

Moreover, processions during such occasions seem to have always been organised so as to provide a spatial classification of various lower social groups (suku) within a shipshaped pattern representing the superior social order (marga). Specific suku were given the names and took the spatial position of the jurubatu (a common Malay name for the mate, in charge of the anchor at the fore part of the ship), or the jurumudi (the helmsman, sitting aft). But possibly the most important transition rite in Lampung, calling for the expression of the complete range of symbols, would have been the socalled papadon ceremony, during which social rank was acquired (the papadon itself was a wooden chair decorated with mythical animals to which the ranked person was entitled in the village balai after going through the ritual). Only those who had raised the papadon were then allowed to erect a kind of arch in front of their houses, decorated with ship, bird and snake motifs. Finally, those who had attained the higest ranks were allowed to ride to ceremonies and adat-meetings in wooden ships on wheels with their bows carved in the shape of hornbills or garudas. The same carriage was used to bring the leaders' bodies, in full regalia, to the graveyard. Houses of highranking persons had cross-beams giving them the high-ranking shape of a boat, and ship-cloths were inserted between the main poles and the roof-beams.

One last example in such a comprehensive inventory, and a very revealing one at that : during the leaders' adat-meetings in the balai, each one of them had the long ship-cloth to which he was entitled hung in front of him, thus creating again another spatial classification of the various social groups within the larger social framework.

Nowhere other than in Lampung country, in the societies from the western half of the Archipelago, do we find such a complex set of symbols converging towards the boat motif. But one may find here and there severals discrete elements of this set represented in rituals. These are mostly found, as expected again, when rites de passage are concerned. If such separate elements have survived, one should think that fuller sets of representations would have been present at some earlier time, when they would still have been essential to revalidate social order at different levels.

Lampung ship-cloths are known to have been given such names as tampan jung galuh (" diamond or princess [?] junk») or tampan jung tiang condong («junk with a raking mast $»)^{16}$. In a similar fashion, such weavings bearing the name kain or songket jong sarat ( « fully laden junk ») appear in Malay or Javanese classical literature. The late Javanese Babad Sembar, describing the attire of a Blambangan prince ready to fight a battle, mentions such a songket jong sarat. During marriage ceremonies in Selangor, the commoner bridegroon's "bridal mat » was replaced, when a Raja was involved, by a " quilt, embroidered in a manner called jung sarat ». In the Hikayat Dewa Mandu, we find a kafan jong sarat appearing in a burial ritual ${ }^{17}$. Thus we find again textiles with boat motifs at least in their names, associated with rank and rites de passage. 

during marriage ceremonies, particularly those of ranked people. The term puan itself does not seem to refer to a boat ; but the vessel is often fitted with a kind of rack called dandan and this, in turn, is the term usually applied to the stem and stern platforms of local boats. Boat-shaped sirih carriers were actually said to be present among the ritual implements of courtly marriage ceremonies described in the 18th century Adat Rajaraja Melayu (Skeat 1949; Sudjiman 1983: 71, 199, 230). The latter seem to have been quite common in the Archipelago from early times. The term lancang (which appears as early as the 9th century in Old Balinese inscriptions within lists of boats) is the High Balinese form used for a betel-container. It is also found as lalancang in Sundanese. The earliest appearance of this boat-name to describe a betel-container seems to be that in the Old Javanase Agastyaparwa. One such gold lancang still belongs to the pusaka of the Susuhunan of Surakarta ${ }^{18}$. Considering this evidence, it is easier to interpret confidently Ma Huan's vivid 15th century description of Javanese marriage rites : when a man escorts his bride home, among other objects, a boat is decorated with areca-nuts, betel-leaves and sewn strings of flowers and grasses by «neighbours friends and relations » (Mills $1970:$ 95). This is clearly a reference to some kind of lancang sirihcontainer.

Most of what has been dealt with to this point refers to rituals performed at household level, or to statements on small socio-political systems. Pre-European (or pre-Islamic) Philippines, which provided me with a starting point, offered a good example of a society in which such polities had probably undergone little influence from imported State conceptions.

21 Ninth century Javanese epigraphs support the view that minor political systems under their own ratu, still little removed from the wanua level, would have been common in Java only three generations earlier (Wisseman 1983: 17). This seems to describe a situation close enough to that found some eight centuries later in the Philippines. In spite of this remark, later Javanese society does not seem, at first sight, to have expressed at state level the kind of statements we have observed elsewhere at a lower level, and that will be observed at state level in Malay societies. The environment is indeed no longer conductive to it in the Central Javanese courts. But the numerous prow-figures still to be found in the court museums of Surakarta and Yogyakarta, that seem to have been part of stately craft used on the Bengawan Solo, could possibly lead to some unexpected discoveries, when properly studied ${ }^{19}$. Various musical themes played in Central Javanese courts still carry names referring to boats: one of these, called babar layar (lit.: "unfurling the sail») was in the 19th century especially reserved in Yogyarkarta for the Sultan and the Crown Prince ${ }^{20}$. Pasisir traditions and their relationship with the maritime environment, also need to be closely investigated with these questions in mind, before any proper conclusion can be drawn regarding Javanese societies ${ }^{21}$. One should furthermore note here that in funeral ceremonies held at court level in ancient Java, boat symbolism was clearly present. During the posthumous ritual (sraddha) in honour of the Rajapatni held in the capital in 1362 (as described in the Nagara Kertagama), bishops and minor funtionaries (mantri) had their offerings brought in boat (banawa)-shaped carriers, «their size: in shape true ships (phalwa)». A century later, Mpu Tanakung describes another such sraddha ritual in his poem Banawa Sekar («Flower Boat»). The offerings are again shaped in various 
symbolic froms, but the most beautiful are those of the host king, in the shape of a boat made of flowers (jong sekar), complete with sail, rudder and keel ${ }^{22}$.

As we move further west, we come across large political systems in which boat symbolism is currently expressed. The Malay Sultanates were obviously quite fond of fully fledged boat metaphors to express their own perception of political institutions.

Nowhere was the "ship of state" metaphor expressed better than in the Perak Sultanate. Perak Malays conceived their negeri explicitly as a ship, with the ruler as her captain (nakhoda) and some of the ministers as members of the crew : they were said to be as the mate (jurubatu) whose station is foward, as the helmsman (jurumudi), " he who wields the chief startboard paddle " (dayong peminggang kanan), i.e. sitting nearest to the part of the ship occupied by the Raja, as the same on the port side, as the poler of the ship (pergalah) or as «the person who bales the ship if she leaks » (timba ruang), i.e. who removes any danger threatening the country ${ }^{23}$.

When the Maritime Laws of Melaka were written down near the end of the 15th century, the same theme was then developed, in an inverted fashion, as if by looking through a mirror. As the ruler was on shore, so was the nakhoda at sea, and the same went for the government and the crew : the helmsman was the bandahara; the jurubatu was the temenggong, and the petty-officers in charge of starboard and port (tukang kanan dan kiri) were the courtiers (Winstedt and de Jong $1956: 30,32,52$ ). On the other hand, the impossibly dangerous situation of the existence of two rulers in one single kingdom is often reiterated in Malay literature with a reference to the situation aboard a ship : "You know how it is in a perahu with two captains and in a country with two kings "24.

A brief excursion further east, into the different cultural context of the Mandar kingdom of Pembawang, and we have the three chief ministers (pa'bicara) together with the officers of their council, who bear the name "the three sails (or masts)" (pallayarang tellu) (Tenriadji $1960: 108)$.

Back into Malay country, in Riau, another well established tradition is that of the Lancang Kuning (the "Yellow Lancang "), taken as a metaphor for the ruler's power and the State ${ }^{25}$. A popular pantun of the area makes this perfectly clear :

Lancang Kuning berlayar malam The Lancang Kuning sails at night

Haluan menuju kelaut dalam Her bows towards high seas

Kalau nakhoda kurang paham If her nakhoda is ignorant

Alamat kapal akan tenggelam she is bound to be wrecked

This should be understood as : "In times of danger, if the ruler is unenlightened, the State will disappear ${ }^{26}$.

Sailing fleets led by the rulers of the Archipelago were obviously necessary for interisland voyages or warfare. As such, they are often referred to in local literature and one is struck by the recurrence of long, often florid, lists of boat names. Such lists appear in early epigraphs such as the $923 \mathrm{AD}$ old Balinese inscription of Sembiran, and they are found again in later Javanese texts such as the Dewa $\mathrm{Ruci}^{27}$. They are usually mentioned in a rather matter-of-fact way. But there are specific occasions which call for special care by the authors and it is no wonder that such occasions are provided, once again, when rites de passage are involved, such as marriages, deaths or foundations. The most remarkable descriptions of such fleets are to be found in Malay literature.

When Lambu Mangkurat of Banjarmasin travelled by sea to Majapahit to request a consort of royal blood for a local princess, he had his fleet prepared, together with his 
« ship of state » named Prabajaksa (which is also the name of the dalem ageng of Central Javanese kratons). The latter's description in the Hikayat Banjar is worth quoting in full, as it is the redundance of the listed symbols, the excessive "decoration", that is meaningful in the present context. "The symbols, "like words in a language", are manipulated to make statements » (Wolters $1982: 84$ ).

« He sailed in full state on board the yacht called Prabajaksa, availing himself of the insignia of royalty left by his father Ampu Jatmaka : two vertical streamers adorned with gold, two tasseled staves adorned with gold, four pennons decorated with gold paint, a braided streamer looking like a centipede embroidered with gold thread and twenty pikes with tufts of red feathers adorned with spangles of gold; his lances had biring blades inlaid with gold, their shafts where decorated with darkred and gold paint, not to mention two state sunshades decorated with gold paint, two state lances shaped like frangipani buds, inlaid with gold and with their shafts banded with gold. The yacht was adorned with marquetry of gold; its sails were of the finest cloth; the clew-lines, the stays and the sheets were of silk and had tassels of pearls; the rudder was of timbaga suasa (a copper and gold alloy), the oars of iron-wood with bands of gold and the anchor gear of undamascened steel. The ships sailing behind her were also fully dressed. » (Ras 1968 : 294-297).

The author of the Hikayat Hang Tuah similarly indulges in an unusually florid description of the royal galley Mendam Berahi (lit. : «Love Madness », built specially to fetch the Princess of Majapahit, with whom the Sultan of Malaka fell in love :

" Her hull was made of planks covered with yellow, red and blue velvet. Her cabin was made of glass and its roof of yellow and red glass, and decorated with pendants of scroll patterns painted yellow, and its door was decorated with losenge patterns. [...] This galley was exceedingly well built. »

31 It is revealing to note the words of the patih Gajah Mada when he reported to his sovereign that a large fleet had laid anchor in his harbour, ant that: " [...] one galley [was] so beautiful that it looked like the conveyance of a king who had come for a marriage proposal.» (Hikayat Hang Toeah 1948, I : 127, 130).

Once again, in the Kidung Sunda, the episode of the princess brought to marry the King of Majapahit is the occasion for a detailed description of the fleet of two hundred large ships and two thousand smaller ones, that carried «to the last man " the people of Sunda, the King and the Queen, all the princes, ministers and their followers, the whole army with arms, buffaloes, horses and elephants, gamelans sounding and banners in the wind (Berg 1927: 16-17, 76-77). Rather than the "ship of state " itself, it is the whole fleet and its passangers that provide the metaphor for the global ordered political system.

One last example, taken from the Sejarah Melayu, once again clearly reveals the ubiquitous symbols of rank and hierarchy, as well as the image of the wholeness of the social group in motion. The occasion is that of the important foundation of Singapura by Sri Tri Buana :

"So vast was the fleet that there seemed to be no counting of it ; the masts of the ships were like a forest of trees, their pennons and streamers were like driving clouds and the state umbrellas of the Rajas like cirrus. So many were the craft that accompanied Seri Teri Buana, the sea seemed to be nothing but ships. (...) and the whole fleet - royal lancang, pelang for royal slumber, court jong, bidar that were paddled, jong with the royal kitchens, teruntum for fishing with the jala net, terentang for bathing [?] - put out to sea with a countless host of escorting vessels ${ }^{28}$.» 

$1911: 60)$. » in their songs :

This is possibly the best rime to recall what Chao Ju-Kua wrote in 1225 about the king of Srivijaya (no « decoration » being attached to this description by a foreigner) : "When the King goes out, he sits in a boat; his body is wrapped in a piece of cloth; he is sheltered by a silk sunshade and guarded by men bearing lances (Hirth and Rockhill

This does not sound like a mere acknownledgement of topographical conditions that would have forced the king to travel always by boat. The description of the (modest) stately pomp of the occasion makes it clear that this is a ceremonial affair : the piece of cloth (a ship-cloth?), the (yellow ?) sunshade and the lances may all be interpreted as symbols of power in a Malay context.

The ritual function of sailing off with a fleet in full state is quite explicit when observed in Eastern Indonesia. Two examples, five centuries apart, will suffice to demonstrate this. In the early 1580's, while sailing in the Raja Empat area, a Portuguese witnessed a fleet «with seven thousand man, who went to sea to mourn the death of their Queen ${ }^{29}$. In present day Tanimbar Islands, the inter-village alliance renewal (in the form of highly ritualised warfare) remains the most striking ceremony. One village gathers a fleet of boats to sail out and meet the other village community. 1 will quote from Susan McKinnon, who observed the ritual :

«In the ritual songs which praise the quality of the boats, they are said to be as swift as birds, as fearsome as sea snakes, as bold as a flash of lightning, and as brilliant as the shimmering sun and moon. Moreover, the boats are laden not only with men and women of high rank, bur also with all the gold and other valuables possessed by the village. The boats of certain villages are said to possess a particularly strong radiance or brillance. »

Later in the ceremony, the visitors dance and the image of the boat is again prominent

" Much praise is lavished upon the form, quality, and cargo of the visitors' boat, which is said to be made of hard, smooth and slick substances. Its prow board is of smooth ironwood, while its keel is of ivory, or of a shiny hard wood. [...] The boat is likened to a cock who struts about displaying his finery: his tall tail feathers, his golden feathers which are like the rays of the sun. [...]. The boat possesses an ivory hull like the new moon. [...]. The flashing brilliance and glory of the boat derives, of course, from the many fine valuables it wears, and from its cargo of nobles dressed in radiant adornments. [...]. The boat trails its fine and flashy decorations, while it wears antique loincloths and sarongs, which are also paradigmatic of persons of high noble birth. [...] the boat promenades, struts, shows off, and laughs.» (McKinnon 1984 : 9-12, 19-20).

One is indeed reminded here of the fully dressed "ship of state " of Banjarmasin, radiant with redundant golden ornaments.

Another theme that needs to be examined is that of the boat burials. Both in Continental and Insular Southeast Asia, as well as in the Pacific, ethnographical evidence points to the fact that boat burials were widespread under a variety of forms, as primary or secondary burials. Archaeological evidence also abounds, from Peninsular Malaysia to Sarawak and the Philippines ${ }^{30}$. The Austronesian vocabulary is again very explicit about this, as the same word often means both "boat" and " coffin " (or else may be related to death) ; bangka/kabang and cognate terms in Java, Sumba or among the Bare'e are a good example of such words. The term kalamba used 
locally for the stone cists of Sulawesi also means «boat $»^{31}$. Malay terms such as larong, or long and its cognate palong, similarly convey both connotations ${ }^{32}$.

Many aspects of boat burial practices may be linked to the quasi-universal belief in psychopomp boats, vehicles needed for the souls to travel to the other world. However, at such a crucial stage, individuals and society need reassuring and the universal order is then clearly expressed. This "ship of the dead», or "flying ship » as it is often termed, whether the coffin proper or a small model used in rituals, is loaded with cosmic symbols : being associated with the celestial hornbill and the chthonian snake, the tree of life and houses, it is also a represenation of the encompassing cosmological sphere (Scharer $1963: 22-23$ ). Within this sphere, at a lower hierarchical level, one also finds the now familiar statement about social order.

On the one hand, in islands such as Timor Laut or Kei, as well as in most of Melanesia, it has been reported that boat burials were a mark of honour reserved for distinguished persons, mostly chiefs, but also priests or warriors ${ }^{33}$. The Borneo Kayan used to build large wooden structures on poles, in which the bodies of a chief, his faithful followers and slaves were placed, together with his war boat (Roth 1968, I : 146-147). On the other hand, mass burials in one large boat bring us even closer to our leading thread : it is the whole "boatload»-i.e. the minimal social group - that follows its leader in his last voyage. Thus the expression of social order is signified all the way through. In Pulu Pengujan, a small island of Pulua Bintan (Riau) there is a large tomb, the stone markers of which are $12.90 \mathrm{~m}$ apart. It is said to be that of an Acehnese panglima buried with his crew and his boat after a battle with the Portuguese in early XVIth century ${ }^{34}$. Whether archaelogical excavations prove this local legend to be founded or not, the mere fact that this kind of statement can be made in Western Indonesia in the XIXth century is sufficient proof that mass burials have not always been an alien practice in the area. The existence of similar practices in Insular Southeast Asia in confirmed by the testimonies or early Spanish chroniclers of the Philippines, where they seem to have been current. As one would have expected, they were associated with the datu and their baranggay, both artefect and socio-practical unit. It is worth quoting the mid-XVIIth century description of a Visayan custom by the Jesuit Francisco Colin :

"A short time before the Faith was brought to the Island of Bohol, one of their chiefs ordered that he be buried in a type of boat they call barangay, together with seventy slaves in arms, ammunition and victuals, in the same manner that he used in his lifetime when he would go out to raid and plunder. $»^{35}$

"Slaves" are the ones to be sacrificed to accompany the datu's soul into its last journey, but it seems reasonable to consider them as substitues for the more complex entourage of a chief (slaves and bondsmen being furthermore a constituent part of the latter's baranggay).

Before concluding this paper and examining various reasons why the boat as an artefact has been imparted such a symbolising potential and was so efficient in suggesting metaphors for social order, I will consider a specific term which has been associated with shipping from earliest historical times and which has survived as the name of a character still very much alive in the folk traditions of the archipelago. The terms is puhawang and the character is usually known as "Sea-captain (jurugan or nakhoda) Dampu Awang ». Analysis of this will provide us with further insights into the symbolising process that takes ships and shipping as its central theme. I will not deal in 
this paper with the Dampu Awang tradition : this desac ralised myth would probably form one of the leading threads of a study in symbolics of exchange systems ${ }^{36}$.

The proper name Dampu Awang has its origins in the Javanese title dang mpu hawang. Dang is an honorific prefix denoting a religious person of distinction ; $(m) p u$ is similarly used for distinguished persons, often but or exclusively of religious status ${ }^{37}$. The possible meaning of (h)awang we will examine later. The title puhawang first appears as a set expression meaning « ship-master » as early as the last quarter of the 7th century $\mathrm{AD}$, in the Srivijayan Old Malay inscription of Telaga Batu. It is often found again with the same meaning in early Malay and Javanese epigraphs, as well as in old Javanese literature, in texts such as the 12th century Smaradahana and Hariwangsa. Its meaning " ship-master " is further confirmed by the Sung shih where a Javanese title of 993 AD is transcribed as p'o ho wang and translated as " master of the ship ${ }^{38}$.

The Malay word pawang clearly derives from the Old Malay puhawang, both phonetically and semantically. It is found in Classical Malay literature with the meaning of « shipmaster $»^{39}$. However, all dictionaries give a wider meaning to the word : a pawang is « an expert in any art believed to need the use of magic » (among which, judging from the examples, fishing is prominent), and also, in some areas, a "shaman, sorcerer, medicine-man $»^{40}$. My point here is not to demonstrate which one of these acceptations antedates the other, but only to bring forward evidence that clearly proves the complementary of both in Austronesian speaking societies ${ }^{41}$.

The chief technical operators, viz. the experts in shipbuilding, in seamanship and/or in fishing seem to have always been the chief performers in the rituals linked to their professional activity ${ }^{42}$. Their expertise is not only that provided by their technical skills, but also that of the religious or spiritual powers they need, being in charge of the government of a discrete social group, and having to fight against powerful natural forces. The Maritime Laws of Melaka when defining the responsibilities of the pilot, clearly state his dual role: as the de facto master of the crew at sea, apart from his numerous technical skills, the malim :

« [...] ought not to forget to pray to Allah and his Prophet to remove all dangers. He is on board as the Imam [is ashore], and the passengers and the crew are as the followers of the Imam in prayer. » (Winstedt and de Jong 1956 : 38-39). Considering this, it is no wonder that the Arabic mualim (" he who knows, who is an expert ; a pilot ») has easily been adopted in the Archipelago with a meaning parallel to that of puhawang/pawang (through a reversed process, malim has come to mean "shaman » among the Kubu of Sumatra ${ }^{43}$.

One is furthermore reminded here of the 682 AD Srivijayan inscription of Kedukan Bukit. Is it a mere coincidence (or am I being carried away by my subject?) that the only known inscription from Insular Southeast Asia which describes a sovereign's two journeys by boat links these events, on the one hand, to the foundation of some kind of polity, for which the term vanua appears (the inscription is very unfortunately broken right after the latter word), and on the other hand, to the acquisition of spiritual power (siddhayâtra), which we know by now is among the prerequisites for a shipmaster, as well as for the ruler whom he often replaces in metaphoric statements? The same term siddhayatra is found in two other Southeast Asian inscriptions. In a Vth century epigraph on the Malay Peninsula, it is associated with a local « great sea-captain ». In a IXth century inscription from Campa, it is linked to a court dignitary who twice travelled by sea to Java. Again, is it a mere coincidence that in the only three Southeast 
Asian inscriptions known to use the term siddhayatra we find this acquisition of spiritual power associated with sea-faring $?^{44}$

As a concluding remark to this disgression on the relationship between the technical and religious or spiritual powers of the ship-masters as leaders of self-contained social groups, one may note a recent resurgence of this statement in modern Philippines. A group of Filipino poets has given itself the name "Caracoa", a term applied to wellknown ships formerly plying the waters of Mindanao or the Moluccas (usually known as kora-kora on the Indonesian side). The editor of their journal justify this choice by stating that in this "caracoa" - a clear metaphor for the Philippine society- «the poet sat alone in the far end of the boat, manning the rudder [...]. He was far back yet he provided direction $»^{45}$. From poet/shaman to helmsman/ship-master, from pawang to puhawang, it is the same concept one is obviously confronted with. In O.W. Wolters' terms, we are dealing with the leardership of "men of prowess ", attributed with an above-average "soul stuff », which explains and distinguishes their performance : signs of spiritual quality would have been the most effective leadership ${ }^{46}$.

One may now proceed one step further in the analysis of the term puhawang. Damais has clearly stated that it should be understood as being composed of the prefix $p u$ followed by hawang, but he did not attempt to provide a meaning for the latter. As noted by de Casparis, hawang has no direct connection with navigation. When it appears in Old Malay or Old Javanese epigrahs, it seems to be a title used by high dignitaries or priests. Zoetmulder adds that it appeared among the persons attached to the kraton $^{47}$. These glosses alone provide no clues as to the etymology of puhawang/ ship-master. However, one may note at this point that among the Brunei Malays, the title awang is borne by an intermediate social class (different from the nobility, but higher than the commoners) which was closely linked to the high non-noble offices (they actually define themselves as the descendants of holders of those offices). But a remarkable point is that the ship-masters/merchants of Brunei (the nakhoda), who used to be highly respected persons, do seem to have been associated with the awang class (Brown 1970 : 11, 14-15, 26-27, 171-172). Though this is not conclusive per se, it brings us one step closer to establishing a relationship between (h)awang and the leadership of a boat.

51 Through most of this paper, we have observed that many statements expressed through boat symbolism could be read in a similar way in varied cultural contexts ranging from the far east to the far west of the Archipelago, in different times and places. Now, recent anthropological researches into classification systems of Eastern Indonesian societies have brought to light some very precise data on symbolic associations of specific parts of the boat. In Halmahera, within the familar dual cosmological and geographical classification sea/inland, the sea is associated with masculine gender, the elder brother, fishing, political life and the aft part of the boat ${ }^{48}$. In Roti, we find the husband associated with the rudder (thus again the aft part of the boat), and in the Kei Islands, he is compared to the shipmaster (the wife-taking group would formerly give a boat during marriage exchanges) ${ }^{49}$.

In the Lampung area, it seems that the upstream suku took the jurubatu's place in ritual processions (thus the fore part of the ship). Though information seems to be lacking on the opposite direction, it is reasonable to conclude from the above that the downstream suku would have taken the jurumudi's place and thus be associated with the aft part of the ship (Gittinger 1972: 35, n.2). This does not tell us about the associations of the 
elder brother, but at least it leads one to believe that classification patterns similar to those of Eastern Indonesia may also have existed in Sumatran societies.

Political life and the aft part of the boat (or the rudder) carry us back to the leadership of the ship-master/helsman on a minimal social unit, a familiar metaphor by now. The elder brother, or the husband, on the other hand, suggest a relationship with Malay or Javanese abang (« elder brother, husband»). Considering that, phonetically, the passage (h)awang abang poses no problem, one cannot ignore that hawang and abang may well be cognates in Malay and/or Javanese (and one should remember that, basing himself on the first quotation he gives, Zoetmulder also glossed hawang as : « master, husband (?); cf. puhawang ») (Zoetmulder 1982 : s.v. hawang 1). The title (h)awang may thus ultimately have had to do with an elder brother's or a husband's authority on a minimal social unit, for which both boats and houses offered the best metaphorical expression (hence the meaning of «ship-master " attached to puhawang). I am quite aware, though, of the fact that such an hypothesis remains, at best, informed speculation, considering that there are as yet no reports of fully fledged classification patterns similar to those of Eastern Indonesia among the Malays or the Javanese.

Having examined multiple boat motifs and having tried to organise into a system their seemingly arbitrary occurrences, the first conclusion that one may draw is that when societies from Insular Southeast Asia make statements about themselves and about the order that structures them, through the detour of a more or less conscious symbolism, the boat is what they quite often view themselves as. I did remark in passing that boat symbolism was far from univocal : many different statements are made when the boat motif is evoked. On the one hand, simple exegesis akin to popular etymologies are often provided to account for its presence: the vessel is taken literally as a means of transportation that mechanically helps in the transition from one stage to another, or even from one island to another, when «migrations » or overseas ancestors are claimed in myths. Of the same order are houses that look like boats (even when such statements are confirmed a posteriori by stuctural charactistics or plain superadded decoration). On the other hand, the main statement which pervades all occurrences of the boat symbol is that of a metaphor for hierarchical levels of social and cosmological systems. Within the all-encompassing cosmological sphere -the boat as a model for the macrocosm - this paper has concentrated on the subsystem in which the boat symbol is used to conceptualise lower hierarchical levels of social, political and economical order : the minimal social unit (in an homo thetical rapport with the house), larger social groups (village, baranggay, suku, marga, etc.), or the largest encompassig unit of this sub-system, the state itself.

The question now arising is: why was the boat used on such a scale to express statements about social structure? Why was it given such a symbolising potential, on a par with the more obvious house? One has to go further than just to state that ships and shipping played a major role in an island society. Answers that would evoke a period when early Austronesian communities would have lived on boat-houses, as the present day Bajaus do, would also be over-simplistic, apart from being contradicted by archaeological evidence. The importance of the ship during overseas "migrations", though taken into account in many local statements, does not seem more adequate. Satisfactory answers, in fact are presently lacking, and will only be provided once archaeologists, historians and anthropologists have devoted more of their activities to studying the region's maritime adaptations, a dimension which appears so depressingly 
under-examined. A line of interpretation which will have to be further verified on the Southeast Asian field may nevertheless be proposed at this stage.

For one thing, ships have always been run according to strict hierarchies, with a clear division between those on board whose job it is to give orders, and those who must obey. This is universally felt as essential to avoid any mishap at sea (and one is reminded here of the common Malay saying about the impossibility of having two captains in a single ship). Anybody who has had some experience in sailing also knows how spatial order is vital on board. Ship-like shapes may thus be seen as an essential organisational principle of an orderly society. In the whole of hierarchical Southeast Asia, social classification is mapped in the ceremonial arrangement in space of individuals or groups of people. The traditional question of a Balinese enquiring about a person's rank: "Where do you sit?", is accurately thought of, in neighbouring societies, in terms of places aboard a ship, thus providing a clear image of social order, as enacted in rituals.

Societies in the Pacific as well as in Island Southeast Asia may also have used metap hors related to the building of boats to illustrate social organisation seen as a network of interactions within an interdependent self-contained unity. The building of a vessel may for one thing be seen as the assembly of a complex structure from a number of simple elements. The resultant vessel is a symbol of group achievements and reinforces group solidarity. Both the building and the using of a boat provide a continuity of ceremonial, social and economic activities, during which the chief technical operator ship-building expert, shipmaster of fishing expert- is also the chief performer of ritual ${ }^{50}$ ( $c$ f. the relationship between the Old Malay and Old Javanese term puhawang, "shipmaster ", and the Malay pawang, now meaning a shaman).

There are but too few studies on marine-orientated groups in Insular Southeast Asia. From the few available, one may gather some corroborative evidence : "boat groups ", " net groups ", «fishing units » of Malay fishermen, passompek working groups of the Makasar sailors, and the models of hierarchy and authority which are attached to them do all provide images of social units similar to those that pervade boat symbolism ${ }^{51}$.

A second set of provisional conclusions concerns the historical development of Southeast Asian political systems (this does take us back to the theme of this Symposium, from which I am afraid I have much drifted away so as to be able to make my point).

There is very little on pre-XIVth century political systems gathered from archaelogy, epigraphy or local and foreign literary sources which may be interpreted within a boat symbolism grid. I believe there is enough of it at this point to justify further researches, for which the present argument would only be a leading thread. Evidence such as that gathered from modern Eastern Indonesia or from XVIth century Philippines can only provide a background for an historical approach to the problem by bringing to light constituent structural elements of Southeast Asian political systems, thus showing what the pre-In dianised or pre-Islamicised political systems would have been like (only to a degree : these societies are not static ones, and any over-simplistic one-to-one identification should be resisted). The richness of the boat motif pattern at the other end of the Archipelago is striking. We have seen how Malay societies, from Srivijaya onwards, were fond of such statements, at all levels. The Lampung case is also interesting: it is one of the richest fields and the fact that it once belonged to the Srivijayan orbe ( $c f$. the Palas Pasemah inscription), makes it even more appealing. 
By constrast, early Javanese political systems look rather withdrawn. As already noted, it is too early to reach solid conclusions as Javanese historiography has always turned its back to the sea. It might nevertheless appear that a different localising process took place within Javanese political systems, which would have left aside the essentials of a set of symbolisms, ritual usages and conceptualisations of the social and political order that pervaded the Southeast Asian cultural matrix. This in a way is a rejoinder to Herman Kulke's question (in his paper given at this same Symposium) as to whether the disappearance of the Srivijayan polity from the Sourheast Asian scene is linked to the emergence of a Javanese power of a different nature in East Java.

\section{BIBLIOGRAPHY}

Adams, M. J., 1974, « Symbols of the Organized Community in East Sumba, Indonesia », Bijdragen tot de Taal-, Land- en Volkenkunde (BKI), CXXX, 2-3 : 324-352.

Adriani, N., 1928, Bare'e-Nederlandsch Woordenboek. Leiden.

Adriani, N. and A. C. Kruyt, 1951, De Bare'e Sprekende Torajdas van Midden-Celebes. Amsterdam.

Andaya, B. W., 1979, Perak, the Abode of Grace. A Study of an Eighteenth-Century Malay State. Kuala Lumpur.

Badarudin, M., 1979, Kehidupan masyarakat passompek di kecamatan Mallusektasik, kabupaten Barru. Thesis, Ujung Pandang

Barraud, Cécile, 1979, Tanebar-Evav. Une société de maisons tournées vers le large. Cambridge.

- 1983, « The sailing boat: circulation and values in the Kei Islands ", Conference on «Contexts and Levels » (Oxford, mars).

Berg, C. C., 1927, « Kidung Sunda. Inleiding, tekst, vertaling en aanteekeningen », BKI LXXXIII : $1-161$.

Blair, E. and G. Robertson, 1903-09, The Philippines Islands, 1493-1898. Cleveland.

Du Bois, J. A., 1852, « De Lampongsce districten op het eiland Sumatra », Tijdschrift voor Nederlandsch-Indië (TNI) XIV : 245-275.

Boxer, C. R. and Pierre-Yves Manguin, 1979, « Miguel Roxo de Brito's Narrative of this voyage to the Raja Empat (may 1581-novembre 1582) », Archipel XVIII : 175-194.

Brandes, J., 1889, « De Koperen platen van Sembiran (Boeleleng, Bali), oorkonden in het Oudjavaansch en het Oud-Balineesch », Tijdschrift voor Indische Taal-, Land- en Volkenkunde (5TBG) XXXIII : 16-56.

Brown, D. E., 1952, « Sejarah Melayu or the Malay Annals ; a translation of Raffles Ms. 18 ", Journal of the Malayan Branch of the Royal Asiatic Society (JMBRAS) XXV : 1-276.

- 1970, Brunei : the Structure and History of a Bornean Malay Sultanate. (Monography of the Brunei Museum Journal, II/2).

Casino, E. S. 
1977-78, « The pocket villagges. How the early settlers beached their boats and became Barangays ", Filipino Heritage III : 744-747.

Casparis, J. G. (de), 1956, Brasasti Indonesia II. Selected Inscriptions from the 7th to the 9th Century AD. Bandung.

Chabbra, B. Ch., 1935, « Expansion of Indo-Aryan culture during Pallawa rule, as evidenced by inscriptions ", Journal of Asiatic Society of Bengal, Letters I, $1: 17-20$.

Chambert-Loir, H., 1980, « Hikayat Dewa Mandu. Épopée malaise, I », Bulletin de l'École Française d'Extrême Orient (BEFEO) CXXI.

Clamagirand, B., 1979, « Li'i Marapu, parole et rituel ches les Wewewa de Sumba Ouest », ASEMIX, 2-3-4 :49-58.

Coedès, G., 1930, « Les inscriptions malaises de Çrîvijava », Bulletin de l'École Française d'ExtrêmeOrient (BEFEO) XXX : 19-80.

Colin, F., 1900-02, Labor Evangelica de los Obreros de la Compañia de Jesus en las islas Filipinas. Barcelone.

Cunningham, C.

1964, « Order in tha Atoni House », BKI CXX : 34-68.

Damais, L. Ch., 1955a, Review of R. Goris, Sedjarah Bali Kuna, Bulletin de l'École Française d'ExtrêmeOrient XLVII : 642-653.

- 1955b, «Études d'épigraphie indonésienne, IV. Discussion de la date des inscriptions » Bulletin de l'École Française d'Extrême-Orient (BEFEO) XLVII : 7-290.

- 1960, «Études sino-indonésiennes, I. Quelques titres javanais de l'époque des Song », Bulletin de l'École Française d'Extrême-Orient (BEFEO) L : 1-29.

- 1980, Ships Cloths of the Lampung, South Sumatera. A research of their Design, Meaning and Use in the Cultural Context. Amsterdam.

Drakard, J., 1984, « Ideological adaptation on a Malay Frontier », 5th National Conference of the ASAA (Adelaide, may).

Effendy, Tenas, 1969, Tjatatan tentang « Lantjang Kuning ». Pekanbaru.

Esterik, P. (van), 1984, « Continuities and transformations in Southeast Asian Symbolism : a case study from Thailand », BKI CXL, $1: 77-91$.

Evans, I. H. N., 1932, « Excavations at Tanjong Rawa, Kuala Selinsing, Perak », Journal of the Federation Malay States Museum XV, 3 : 79-134.

Firth, R., 1946, Malay Fishermen : their Peasant Economy. London.

Fox, James, 1973, « On bad death and the left hand : a study of rotines symbolic inversions », pp. 342-367, in R. Needham (ed.), Right and Left : Essays on Dual Symbolic Classification. Chicago.

- 1980, The Flow of Life. Essays on Eastern Indonesia. Cambridge/London.

Fraser, T. M.

- 1960, Rusembilan : a Malay Fishing Village in Southern Thailand. Ithaca.

Friedericy, H. J.

- 1931, « Aanteekeningen over Adat en Adatrecht bij de Bonesche Prauwvaarders », Kol. Tijds XX : 490-504.

Gittinger, M. S., 1972, A Study of the Ship Cloths of South Sumatra : their Design and Usage. PhD. Dissertation, Columbia University. 
Harrison, T., 1958, « The caves at Niah : a history of prehistory », Sarawak Museum Journal VIII : 549-595.

Hikajat Hang Toeah, 1948, Balai Poestaka, tjet. Ke-2, 2 vols. Djakarta.

Hirth, F. and W. W. Rockhill, 1911, Chau Ju-Kua: His Work on the Chinese and Arab Trade in the Twelfth and Thirtheenth Centuries, entitled Chu-fan-chi. Saint-Petersburg.

Holmgren, R. and A. E. Spertus, 1979, « Tampan Pasisir : Pictorial Documents of an Ancient Indonesia Coastal Culture », pp. 157-198, in M. Gittinger (ed.), Indonesian Textiles. Irene Emery Roundtable on Museum Textiles. Proceedings. Washington.

Holt, C., 1967, Art in Indonesia. Continuity and Change. Ithaca/London.

Hoop, A. N. J. Th. van der, 1949, Indonesische Siermotiven. [Jakarta].

Huber, E., 1911, « Etudes indochinoises, IX. L'épigraphie de la dynastie de Dong-duong », Bulletin de l'Ecole Française d'Extrême-Orient (BEFEO) XI : 268-311.

Jasper, J. E. and Mas Pirngadie, 1927, De Inlandsche Kunstnijverheid in Nederlandsch Indië. IV. De Gouden Zilversmeedkunst. 's-Gravenhage.

Kana, N. L., 1980, " The order and Significance of the Savunese House », pp. 221-231, in Fox (ed.), The Flow of Life. Essays on Eastern Indonesia. Cambridge/London.

- 1983, Dunia Orang Sawu. Jakarta.

Kern, H., 1920, « Mengelingen. Kawi en Javaansch », Verspreide Geshriften IX : 191-208.

- 1930, Catalogus der Boegineesche I La Galigo handschriften in de Leidsche Universiteits bibliotheek en elders. Leiden.

Lewcock, R. and G. Brans, 1975, « The boat as an Architectural Symbol », pp. 107-116, in P. Oliver (ed.), Shelter, Sign and Symbol. London.

Lombard, Denys, 1980, « Le thème de la met dans les littératures et les mentalités de l'Archipel insulindien », Archipel XX : 317-328.

Macdonald, Charles, 1979, « Un mythe Palawan : Lali et le Chemin du Ciel », Asie du Sud-Est et Monde Insulindien (ASEMI) X/2-3-4 : 59-85.

Macknight, C. C. and Mukhlis, 1979, « A Bugis Manuscript about praus », Archipel XVIII : 271-282.

Mackinnon, S., 1984, "The Coolness of Peace, the Heat of the Contest : Intervillage Alliances in the Tanimbar Islands ", Seminar Penelitian Maluku dan Irian Jaya, Ambon (January).

Mills, J. V. G. (ed.), 1970, Ying Yai Sheng Lan. The Overall Survey of the Ocean Shores. Cambridge (Hakluyt Society).

Nimmo, H. A., 1972, The Sea People of Sulu. San Francisco.

Overbeck, H., 1926, « Silslah Melayu dan Bugis dan Sakalian Raja-raja-nya », Journal of the Malayan Branch of the Royal Asiatic Society (JMBRAS) IV/3 : 339-381.

Panganiban, J. V., 1972, Diksunaryo-Tesauro Pilipino-Ingles. Quezon.

Patanñe, E. P., 1977-78, « The Baranguay. Origin of our Basic Socio-political Unit », Filipino

Heritage III : 755-756.

Paterno, P. A., 1892, Barangay. Madrid.

Pelly, Usman, 1975, Ara, dengan perahu Bugisnya. (Unpublished report, PLPIIS), Ujung Pandang. 
Pigeaud, Th. G. Th., 1938, Javaanse Volkvertoningen. Bijdrage tot de Beschrijving van Land en Volk. Jakarta.

- 1960-63, Java in the Fourteenth Century. A Study in Cultural History. The Nagara-Kertagama by Rakawi Prapañca of Majapahit, 1365 AD. The Hague.

Poerbatjaraka, R. Ng., 1940, « Déwa-Roetji », Djawa XX : 5-38.

Pou, S., 1981, « Notes historico-sémantiques khmères », ASEMI (Asie du Sud-Est et Monde Insulindien) XII : 111-124.

Quirino, C. and M. Garcia, 1958, « The manners, Customs and Beliefs of the Philippine Inhabitants of Long Ago ; being Chapters of'A late Sixteenth Century Manila Manuscript', transcribed, translated and annotated ", The Philippine Journal of Science LXXXVII : 325-454.

Ras, J. J., 1968, Hikayat Bandjar. A Study in Malay Historiography. The Hague (Bibliotheca Indonesica, 1).

Reid, L. Anthony, 1971, Philippine Minor Langugaes. Word Lists and Phonologies. (Oceanic Ling., Sp. public. No. 8), Honolulu.

Scharer, H., 1963, Ngaju Religion. The Conception of God among a South Borneo People. The Hague.

Schnitger, F. M., 1964, Forgotten Kingdoms in Sumatra. Leiden.

Scott, W. H., 1982, «Boat-Building and Seamanship in Classic Philippine Society », Philippine Studies XXX : 335-376.

Shellabear, W. G., 1885, "Titles and Offices of the Officers of the State of Perak ", Journal of the Straits Branch of the Royal Asiatic Society (JSBRAS) XIV : 6-7.

Shorto, H. L., 1971, A Dictionary of Mon Inscriptions from the Sixth to the Sixteenth Centuries. London.

Skeat, W. S., 1949, «The Malay Boat-Shaped Puan », Journal of the Malayan Branch of the Royal Asiatic Society (JM BRAS) XXII : 180-181.

Skeat, Walter William, 1900, Malay Magic. London.

Sorensen, S. A., 1972, « The Flying Ship in Indonesia », pp. 65-75, Ethnogr. Museum, University of Oslo, Yearbook.

Steinmann, A., 1937, «Les "tissus a jonques" du sud de Sumatra », Revue des Arts Asiatiques XI : 122-137.

- 1940, « Das kultische Schiff in Indonesien », Jahrbuch für prähist. und ethn. Kunst XIII-XIV : 149-205.

Sudjiman, P. H. M., 1983, Adat Raja-raja Melayu. Jakarta.

Tenazas, R. C. P., 1973, « The Boat-Coffin Burial Complex in the Philippines and its Relation to Similar Practices in Southeast Asia », Philippine Quart. of Culture and Society I, 1 : 19-25.

Tenriadji, A.

1960, "Tjatatan tentang peraturan ${ }^{2}$ hukum adat zaman dahulu kala di Mandar », Bahasa dan Budaja VIII, 3-4 : 107-116.

Tippet, A. R., 1968, Fijian Material Culture. A Study of Cultural Context, Function and Change. (Bernice P. Bishop Museum Bulletin 232) Honolulu.

Tobing, Ph. O. L., 1977, Hukum Pelayaran dan Perdagangan Amanna Gappa. Ujung Pandang.

Toth, H. Ling, 1896, The Natives of Sarawak and British North Borneo. London. 
Vroklage, B. A. G., 1936, « Das Schiff in den Megalithkulturen Südostasiens und der Südsee », Anthropos XXXI : 712-757.

- 1937, « The Ship in the Megalithic Culture of Indonesia ", Nederland Mail III, $11: 306-308$, IV/6165-168, IV/8 : 221-224.

- 1940, « De Prauw in de Culturen van Flores », Cultureel Indië II : 193-199.

Wilkinson, R. J., 1959, A Malay-English Dictionary (Romanized). London.

Winstedt, R. O., 1938, « The Malay Annals, or Sejarah Melayu », Journal of the Malayan Branch of the Royal Asiatic Society (JMBRAS) XVI : 1-226.

Winsredt, R. O. and P. E. Josselin de Jong, 1956, « The Maritime Laws of Malacca », Journal of the Straits Branch of the Royal Asiatic Society (JSBRAS) XXIX : 22-59.

Wisseman, J., 1983, « Raja and Rama : the Classical State in Early Java », pp. 9-44, in L. Gesick (ed.), Centers, Symbols and Hierachies : Essays on the Classical States of Southeast Asia. (Mon. Ser. 26 ; Yale Univ. SEA Studies), New Haven.

Wolff, J. V., 1972, A Dictionary of Cehuano Visayan. (Data paper 87, Cornell Univ. SEA Program), Ithaca.

Wolters, O. W., 1979, «Studying Srivijaya », Journal of the Malayan Branch of the Royal Asiatic Society (JMBRAS) LII : 1-32.

- 1982, History, Culture and Region in Southeast Asian Perspectives. Singapore.

Woodward, H. W., 1980, «Indonesian Textile Patterns from a Historical Point of View », pp. 15-35, in M. Gittinger (ed.), Indonesian Textiles. Washington.

Wouden, F. A. E. van, 1968, Types of Social Structure in Eastern Indonesia. The Hague.

Yoshida Hirohiko, 1980, « The Boat Motif as seen in Material Culture in Eastern Sumba, Indonesia, and its Surroundings », [In Japanese, with an English Summary], Minzokugaku kenkyu XLV : 244-262.

Zoetmulder, P. J., 1982, Old Javanese-English Dictionary. 's-Gravenhague.

\section{NOTES}

2. The subject of this paper has compelled me to cover a wide geopraphical area and to write about cultures with which I have little or no familiarity. In doing so I have had to rely on the help of specialists from various horizons. For the sake of brevity, I wish to thank them all here at once. Peter Carey, Henri Chambert-Loir, Soedarmadji Damais, James Fox, Jean-François Guermonprez, Gilbert Hamonic, Charles MacDonald, Christian Pelras, William Henri Scott, Nikita Sibéroff, Léontine Visser and Peter Worsley have all contributed, in no small way, to the present work. They will recognize their contributions as they read through it, For the risks taken in dealing with such scattered data, and for the unavoidable misinterpretations, I assume full responsability. This text was first published in Southeast Asia in the IXth to XIVth centuries, edited by D. G. Man and Anthony C. Milner, Singapore/Canberra : Institute of Southeast Asian Studies (1986). It appears here with with no modifications

3. Gittinger (1972) ; Holmgren and Spertus (1980) ; van Dijk and de Jonge (1980). Woodward (1980) provides a clear picture of the art historian's new approach to Indonesian textiles.

4. On the Eastern Indonesian "field of studies", see van Wouden (1968) and James Fox's introduction to the book he edited (1980). Recent studies dealing specificially with boat and 
house symbolism are : Adams 1974 ; Barraud 1979, 1983 ; Kara 1980, 1983 ; McKinnon 1984 ; Visser (personal communication) : Yoshida 1980. See also Cunningham 1964.

5. I should mention here Denys Lombard's work on the "theme of the sea " (1980). His is a different approach, which does not discuss the boat motif as such, but deals with the metaphysical perception Indonesian societies have of the sea. Tobing had also touched upon various aspects evoked in this paper in his commentary of the Bugis Amanna Gappa code of maritime laws. Among features of what he called an "Indonesian totalitarian mentality ", he listed the perception of the boat as a macrosocm, in relation with the total social macrocosm. He carried out this demonstration to find the origns of gotong royong, guided democracy and economy (Tobing $1977: 71 \mathrm{ff}$ ) after a thesis written in 1961.

6. On this last approach, see van Esterik 1984 (specifically p. 87).

7. Customs of the Tagalogs (Blair and Robertson 1903-09, VII : 174).

8. See, for instance, the titles of two recent articles : « The Pocket Village. How he Early Settlers Beached their Boats and Became Barangays " (Casiño 1977-78), or « The Barangay, Origin of our Basic Sociopolitical Unit » (Patanñe 1977-78). This theory was first brought forward by Paterno (1892). One may also refer to the even more "official» political pamphlet by A.G. Gabot (Barangay: People Power The Philippines' Grassroot Government from Magellan to Marcos [sic], Manila 1976).

9. Panganiban 1972 :s.v. ; Reid $1971: \mathrm{N}^{\circ}$ 41. It is intersting to note that Panganiban gives the term barkada ot its affixed form barkadahan (from the Spanish, literally a "boatload of passengers ») as another synonym of baraggay. On the boat itself as described in Spanish sources and as found in recently discovered wrecksites in Butuan, see Scott 1982.

10. Kabang (abang) is clearly related to the very common Austronesian word bangka/wangka (usually for «boat ») by metathesis ; for examples of kabang in Philippine languages, see Reid 1971 : Nos 41-142. Cognate terms are also found in Mon-Khmer languages (see the Old Mon kbang for « sea-going vessel »; Shorto $1971: 67$ ).

11. In Old Javanese, the two terms wanua/wanwa for «inhabited place or ares, village, settlement ", and specifically for the smallest political unit, and banawa for «boat, ship » are now clearly differentiated; linguists, to the best of my knowledge, have not claimed for them a common origin (Zoetmulder 1982 : s.v. banawa actually proposes, with a questionmark, a rather improbable Sanskrit etymology). I am not competent to decide whether the median $u$ and $a$ have both evolved from a common root. However, considering the fact that the Ngaju term for boat is banawa, with a median a (Schärer 1963), and the general Austronesian context of boat/social unit correspondence, I would tend to think that wanua and banawa may be cognates. The dual association boat (load)/house (hold) should actually be prolonged into a broader latent configuration : the word banawa may also mean « heaven » or « forest » in various languages of the Philippines (MacDonald, personal communication).

12. From the 1st edition of 1754 ; reference kindly sent to me by W.H. Scott.

13. See references given in note 3 .

14. They are also said at times to "look like them "; the same goes, among others, for Toraja houses. But the boat-shape of the roofs derives from architectural techniques, rather than the opposite: the "faitière tendue", for instance, is one of the most widespread carpentry techniques in Southeast Asia (it already appears on Bronze Age artefacts; Dumarçay 1981); despite the external appearance it gives to roofs, this has nothing to do with shipbuilding. It is thus a misinterpretation to say that houses look like boats because their architecture has been influenced by shipbuilding (Lewcock \& Brans 1975).

15. Data on the Lampung boat motifs were collected from Schnitger (1964: 197-202), Steinmann (1937), Gittinger (1972), Holmgren and Spertus (1980) and van Dijk \& de Jonge (1980). Narrow interpretations of ship motifs may also be found in van der Hoop (1949: cxliv-cxlv) and Holt (1967 : 21-22). 
16. Steinmann (1937: 122) translates galub by « large », for some unknown reason. The name jung tiang condong is that given to a tampam in the Musée de l'Homme, Paris, Département Océanie (pièce 34.71.28) acquired in Palembang in 1934.

17. Winarsih Arifin, Babad Sembar, canto II/24 (in preparation, soon to be published by the EFEO) ; Skeat 1900 : 380 ; Chambert-Loir 1980 : 278, 327 ; Wilkinson 1959 : s.v.jong.

18. On all this see the long note in Damais 1955 : 649-650, and Jasper \& Pirngadie $1927: 239$, fig. 354.

19. See Pigeaud (1938 : para. 196) for a description of such a river journey, on a wedding occasion. 20. Peter Carey, personal communication, 14 May 1984.

21. I have not as yet been able to ascertain the significance of the boat-motif appearing in the kapal kandes ("stranded ship ») pattern of Pasisir batiks.

22. Pigeaud 1960 -63, I : 50-51 ; III : 77 ; IV : 192-193 ; Zoetmulder 1974 : 365-366 ; 506-507.

23. Shellabear 1885 ; Andaya 1979 : xiii,28. B. Andaya illustrates this with a 1876 map of the state of Perak said to represent it in the shape of a ship. H. Chambert-Loir kindly read the jawi legends for me : it appears that there are no references to a ship or its crew in this map.

24. Tuhfat al-Nafis, quoted in Drakard 1984, where this ideological statement is discussed at length.

25. Effendy $1969: 12-13$. Similarly, the ships belonging to the heroes of the Bugis epic I La Galigo should be considered when these texts are studied in more detail. Sawerigading's ship, the Wakka Tana, is loaded with cosmic symbols, and its name alone is revealing: wakka, for "ship ", is cognate to bangka : tana is understood as both the territory and its inhabitants (Kern $1930: 174$ ).

26. Professor J.M. Gullick kindly informed me that during the 1955 elections of Malaysia, the UMNO party polling symbol - a very effective one it seems- was a ship. It is tempting to interpret this as the resurgence of a traditionnal Malay symbol.

27. Brandes $1889: 44,46$. Poerbatjaraka $1940: 9-10$ (the Dewa Ruci dates from the 15th or the 16th century, depending on interpretations ; but the list of boats could well be a later interpolation). The Silsilah Melayu dan Bugis provides a good array of verv matter of fact descriptions of Malay war fleets (Overbeck $1926: 360,370,374$, etc.).

28. Winstedt 1938: 58-60 ; Brown 1952: 28-29; my own translation for the passage with the various types of craft.

29. Boxer and Manguin (1979: 188 , and n.48 for references to another such 16 th century example taking place in « Papua »).

30. Evans 1932; Harrison 1958: 584-590; the best summary to date on such archaeological evidence is that of Tenazas 1973.

31. Adriani 1928 : s.v.; Adriani and Kruyt 1951, II : 481 ; Vroklage 1940 : 223-234. On funerals in Roti, boat-coffins and boat symbolism see Fox 1973.

32. Wilkinson 1959 : s.v. Terms akin to Malay long (« coffin») or palong (« dug-out canoe») are also to be found in many Austronesian languages (from a Proto-Austronesian base meaning « to hollow out »); they designate a "dug-out» craft. The same applies to the Mon-Khmer root lung (cf. Shorto 1971 : s.v. dlung; Pou 1981 : 112-114). Boat-coffin burials are common in Continental Southeast Asia as well: Vietnamese archaeologists have found many such burials in sities pertaining to the Dông-son culture (personal communication by Professor Trân Quôc Vuong).

33. Vroklage 1936: 718. Birket-Smith (1973: 56-57) is useful in summarising most of this evidence in a very short form.

34. Information kindly offered me by Bapak Hamza Yunus of Pulau Penyengat (in December 1981, while working in the area with a team of the Pusat Penelitian Arkeologi Nasional). The source of this evidence is a manuscript in Bapak Hamza's possession (Berita District van Bintan, by Muhamad Apan, ca. 1934).

35. Colin 1900-01,1:69; another such example is given in the late-XVIth century manuscript known as the Boxer Codex (Quirino and Garcia 1958 : 415-416). 
36. The best account of the Dampu Awang problem is provided by Worsley's commentary on the Babad Buleleng (Worsley 1972 : 10, 25, 143-147, 222-223).

37. Zoetmulder 1982 : s.v.

38. de Casparis 1956 : 20, 32-37 ; 209, 358, 367 ; Kern 1920 : 196-197 ; Damais 1960 : 25-29.

39. See, for instance, the Sejarah Melayu (Winstedt $1938: 78)$. Juragan or nakhoda have in modern times replaced pawang/puhawang.

40. See, among other dictionaries, that of Wilkinson (1959).

41. In languages other than Malay or Javanese, titles such as the Bugis puang, used for persons of high rank (though not for the nobility), and specifically for the bissu priests, most probably are cognates of pawang/puhawang.

42. See, for instances, what Friedericy (1931: 501-503) has to say on the «magical powers » of the nakhoda of Bone; Pelly (1975: 14, 70-73) on the Ara shipbuilders; Firth (1946: 122-125) and Frazer (1960:51) on Malay fishermen.

43. Wilkinson 1959 : s.v. malim. One may also add that in many rituals of the Archipelago the shaman is said to be the helmsman of the "flying boat " and to pilot man " out of darkness and into light ; out of sickness into health ; from death into life », etc. (Sharer $1963: 137)$.

44. Coedès $1930:$ 34-35, Chabbra $1935: 19$; Huber $1911: 309$.

45. Caracoa, the Poetry Journal of the Philippine Literary Arts Council, I, 1982.

46. Wolters 1982 : chap. 1 and append. 1.

47. Damals $1960: 27$, n.5 ; de Casparis 1956 : 208-209 ; Zoetmulder 1982 : s.v. hawang 2.

48. Leontine Visser (personal communication).

49. Barraud (1983); James Fox, personal communication, June 1984.

50. See Tippet (1968: $84 \mathrm{ff}$ ) on the symbolism attached to the « sacred canoe » of the Fiji Islands. For similar interpretations of boat symbolism in East Sumba, cf. Adams $1974: 337$.

51. See Firth 1946 ; Fraser 1960 ; Pelly 1975 ; Badarudin 1979.

\section{ABSTRACTS}

The symbolic of all boats motives goes far more beyond than the "cult ship" or the "death ship". They represent the society as a whole, both symbolically and poetically. Thus, this motives, already found in the old Dongson civilization is scattered through Insular Southeast Asia, and found among the sumatrese ship cloth, the javanese symbolical social order, and in many other contexts.

La symbolique des motifs de bateau va plus loin qu'un simple « culte du bateau » ou «bateau de la mort». Ces motifs représentent la société dans son ensemble, symboliquement et poétiquement. Ainsi ce motif déjà présent dans la civilisation dongsonienne, est disséminé à travers l'Asie du Sud-est insulaire ; on le trouve dans les tissus à jonque de Sumatra, dans l'ordre social symbolique à Java et dans beaucoup d'autres contextes.

El simbolismo de los motivos de barcos va más allá que un simple « culto del barco » o « barco de la muerte ». Representa la sociedad en su conjunto, simbolica y poeticamente. Así, ese motivo, ya presente en la civilización dongsoniana, es diseminado a través de las islas del Asia del Sudeste ; se lo encuentra en los vestidos de juncos de Sumatra, en el orden social simbólico de Java y en muchos otros contextos. 
INDEX

Mots-clés: Asie du Sud-Est, bateaux, décorations symboliques, systèmes politiques

\section{AUTHOR}

\section{PIERRE-YVES MANGUIN}

École Française d'Extrême Orient (EFEO), 22 avenue du Président Wilson, 75116 Paris 